\title{
The Impact of Development Induced Displacement on the Livelihood of Small Holder Farmers; the Case of DejenWoreda Rural Kebeles
}

\author{
Demeke Siltan \\ Department of Social Work, College of Social Science and Humanities, Ambo University, Ambo, Ethiopia \\ Email address: \\ demekesiltan@yahoo.com
}

To cite this article:

Demeke Siltan. The Impact of Development Induced Displacement on the Livelihood of Small Holder Farmers; the Case of DejenWoreda Rural Kebeles. International Journal of Sustainable Development Research. Vol. 5, No. 1, 2019, pp. 9-17. doi: 10.11648/j.ijsdr.20190501.12

Received: January 11, 2019; Accepted: February 16, 2019; Published: March 11, 2019

\begin{abstract}
Development-induced projects are factor for involuntary migration to urban areas for the search of better employment raised the rate of vulnerability for socio-economic inequalities. The aim of thisstudy was to assessed the impact of development induced displacement on the livelihood of small holder farmers. The study employed mixed methods approach with case control design. Quantitative data were gathered through structured questionnaire and qualitative data were collected via interview and focus group discussion.By using Census survey and systematic random sampling a total of 162 cases (displaced) and 162 controls (non-displaced households) participated in the study respectivelly. The study employed a modified sustainable livelihood conceptual framework by incorporating basic elements of the frame work The finding revealed that compared to the controls, the cases have lower size of land holding, average livestock holding(1.45 ha vs1.1 ha), (1.804 vs. 2.574 for oxen; 0.936 vs. 1.56 for cows respectively). The controls average annual income is higher than the cases ( 31,000 vs. 23600 respectively). Greater proportion of displaced households $(76.2 \%)$ than the non-displaced households $(9.7 \%)$ perceived that their annual income is decreases within the five years preceding the survey. Compared to controls, large proportion of cases couldn't able to meet the basic needs of the household (55.1\% vs. 23.2\%). The fining also revealed that the amount of money paid as compensation for the displaced households is not fair/ enough as compared with what they lose. Therefore the government should provide fair amount of compensation for displaced households.
\end{abstract}

Keywords: Displacement, Development Induced, Livelihood, Compensation

\section{Introduction}

Development-induced displacement (DID) is forcing of communities and individuals out of their homes, often also their homelands. It is described as dislocation of people from their native place and region. Displacement involves not only the physical eviction from the natural dwelling of the people but also the expropriation of the most productive lands of rural farmers [4]

Each year at least fifteen million people are forced to leave their former place of residence as a result of major development projects [4]. Because of development projects at least 300 million people has displaced between $1988-2008$ across the world [12]

Recently growing development projects and expansion of infrastructures increases the demand for land to the projects.
To accommodate such projects, transferring large amount of land for the needed project/investment activity becomes a necessity. However, much of land needed for such a purpose is already occupied by people that lead to displacement from their farm land for development projects in the project area setting [1]

In Ethiopia, development induced displacement is becoming a great concern in different parts of the country at different level. Displacements aiming at the extension of irrigation and hydropower production referred to as dam induced displacement, provision of better housing in urban centers, large scale agriculture investment projects, and conservation of wildlife via national parks are the major causes of displacement in Ethiopia [8]

According to the current constitution of Ethiopia, land is owned by the state and people have only the right to use [5] 
The constitution states that: The right to ownership of rural and urban land, as well as of all natural resources, is exclusively vested in the State and in the peoples of Ethiopia. Land is a common property of the Nations, Nationalities and Peoples of Ethiopia and shall not be subject to sale or to other means of exchange (Article 40(3)).

In Dejen Woreda, because of development projects, farm land is taken from the rural households and it is the cause for the evacuation of about 162 rural households from their farm land. From the kebeles' of the woreda, three kebeles namely Gelgele, Qoncher, and Zemetin are exposed of the problem and more than 85 hectare of farm land is taken from this farmers and it brings about an impact on the livelihoods of the households since these households livelihood is extremely depends up on agriculture.

This study therefore, is intended to examine the impact of development induced displacement by giving special emphasis on the livelihood of rural small holder farmers: the case of Dejenworeda rural kebeles that has been unnoticed by ant of preceding researchers. This study has the following research objectives; examine the livelihood resources of the households, explore the livelihood strategies pursued by the households and lastly it examines the perceived livelihood outcome of households and land expropriation process and compensation issues of displaced households.

\section{Material and Methods}

The study was carried out in 2016/2017in Dejen woreda, (Figure 1).The study area is located in Eastern Gojjam Amhara regional state of Ethiopia, $229 \mathrm{~km}$ far from the capital city of the country, Addis Ababa. Majority of the population of the study area are highly dependent on agricultural especially production of crop such as teff, wheat maize, sorghum, and others and animal rearing as a supplementary livelihood strategy.

To undertake this study, mixed research design was employed. Specifically case control mixed method design was applied. Three major approaches were used in data collection. First, three focused group discussions were carried out, that is, one from displaced household, another from non-displaced households and third from both (displaced and non-displaced households) has been conducted. In the focus group discussion, 24 farmers, eight household heads in each three groups participated in the discussion

\section{In-depth Interview}

It was another way of data collection instrument for this research; by using this instrument, the researcher has got more information in greater depth from informants. The researcher has interviewed seven individuals (three elders, two youths one male and female, one valuation expert and one female headed household) the researcher tried to keep interview till the data get saturated.

Census survey and systematic random sampling procedure has been used to select 324 smallholder farming households thatis, 162 displaced (via census survey) and 162 non displaced households from the 3 study sites (Gelgele Zemetin and Qoncher) has been selected in proportion with displaced households (Figure 1). The survey was carried out using a standard questionnaire with structured and non structured questions relevant to the study. The questionnaires were developed and tested during a pilot survey. Data were analyzed using statistical package for social scientists (SPSS) and excel with a general framework of contrasting the assets and livelihood strategies for both groups of households studied.

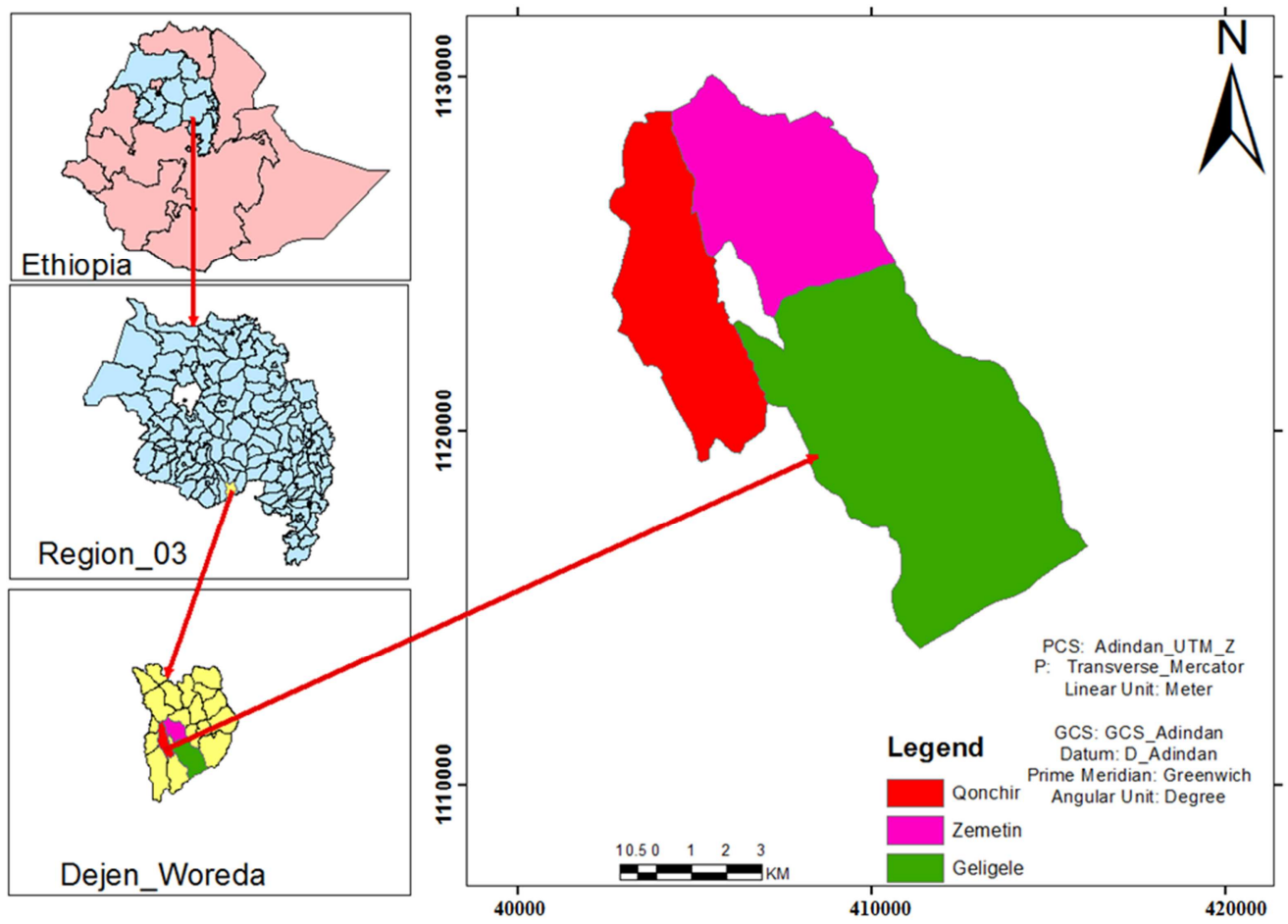

Figure 1. Map of the study area. 


\section{Results}

\subsection{Socio Demographic Characteristics of Respondents}

The socio demographic characteristic of the sample households is presented by the following table.

Table 1. Background characteristics of respondents $(N=311)$.

\begin{tabular}{llll}
\hline & & Displaced households(n=156)\% & Non displaced household(n=155)\% \\
\hline \multirow{2}{*}{ Sex of respondents } & Male & 76.3 & 77.1 \\
& Female & 23.7 & 21.9 \\
Marital status & Married & 87.2 & 85.5 \\
& Others & 12.8 & 14.5 \\
Age of respondent & $25-50$ & 59.0 & 57.2 \\
& Greater than 50 years & 41.0 & 42.8 \\
Educational status & Illiterate & 81.4 & 78.5 \\
& Literate & 18.6 & 21.5 \\
Family size & $1-5$ & 50.6 & 58.1 \\
No of individual that had & $6-10$ & 49.4 & 41.9 \\
economic contribution & $1-4$ & 78.1 & 79.1 \\
\hline
\end{tabular}

Source; household survey, 2017.

Table one reveals the socio-demographic characteristics of the respondents. In terms of sex composition of respondents, $76.3 \%$ displaced and $77.1 \%$ of non-displaced households were males and $23.7 \%$ displaced and $21.9 \%$ non-displaced households were females. $87.2 \%$ displaced and $85.5 \%$ of non-displaced households are married whereas $12.8 \%$ displaced and $14.5 \%$ of non- displaced households are single, divorced and widowed. In terms of age composition $59.0 \%$ of displaced and $57.2 \%$ of non-displaced households are found in age range of $26-50$ and $41 \%$ displaced and $42.8 \%$ of non- displaced households were found above 50 years of age. In terms of educational status $81.4 \%$ of displaced and $78.5 \%$ of non- displaced households are illiterate whereas
$18.8 \%$ displaced and $21.5 \%$ of non- displaced households are literate. In the case of family size $50.6 \%$ of displaced and $58.1 \%$ of non-displaced households have $1-5$ member in their family whereas $49.4 \%$ of displaced and $41.9 \%$ of nondisplaced households have 6-10 family member in their household.

\subsection{Natural Capital (Ownership of Land) in the Household'}

The first and most valuable asset or capital for the rural households is natural capital which includes resource is land and Table 2 below presented possession of farm land among respondents.

Table 2. Percentage distribution of households by their land ownership status $(N=311)$.

\begin{tabular}{lll}
\hline \multirow{2}{*}{ Type of displacement } & Land holding status & \\
\cline { 2 - 3 } & Yes & No \\
\hline Displaced & 92.3 & 7.7 \\
Non displaced & 100 & - \\
\hline
\end{tabular}

Source; household survey, 2017.

Table 2 revealed percentage distribution of households by their land ownership status and 92.3\% of displaced households have their own land $7.7 \%$ of displaced households do not have their own land totally.

Table 3. Average land holding size in hectare $(N=299)$.

\begin{tabular}{lll}
\hline \multirow{2}{*}{ Types of displacement } & Land holding size in hectare & Std. Deviation \\
\cline { 2 - 3 } & Mean & .511866 \\
\hline Displaced & 1.18403 & .473286 \\
Non displaced & 1.42742 & -4.272 \\
\hline
\end{tabular}

Notes $* * *=\mathrm{P}<0.001$.

Source; household survey, 2017

As indicated in table 3, the average land holding size in hectare for displaced and non- displaced households respectively were 1.427 ha and 1.1840.The independent samples t-test result indicated that land holding size of nondisplaced households is significantly higher than the displaced households $(\mathrm{t}=-4.272, \mathrm{p}<.001)$. Hence, the finding of the study indicates that displaced households have small amount of farm land when it is compared with non- displaced households. 
Table 4. Average land holding size of displaced households before displacement and their current possession (N=156).

\begin{tabular}{llll}
\hline \multirow{2}{*}{ Displacement status } & \multicolumn{2}{l}{ Land holding size in hectare } & t-Test \\
\cline { 2 - 3 } & Mean & Std. deviation & $22.342^{* * *}$ \\
\hline Before displacement & 1.681 & 0.6675 & 0.5929 \\
After displacement & 1.112 & & 229 \\
\hline
\end{tabular}

Notes $* * *=\mathrm{P}<0.001$.

Source; household survey, 2017.

As it is depicted on table 4the average land holding size for displaced households in hectare before displacement and their current possession were 1.681 ha and 1.112 ha respectively Apaired samples t-test result shows that there isa significant difference (reduction) in terms of land possession after displacement $(\mathrm{t}=22.342, \mathrm{df}=153, \mathrm{p}<.001$. $)$

Therefore the finding of this study and the statistical results on the table reveals that, there was a significance declination of possession of farm land among displaced households after displacement. In other words, land holding size of the households' decreases' after displacement.

To the discussants and informants the amount of land is dimensioning from year to year at alarming rate. From the very beginning there is shortage of land in the localities because the area is densely populated. At one side there is establishment of factories the government and by investors; on the other hand the town (Dejen) is expanding towards the rural residences. Because of this and other factors, land is decreasing from time to time.

Therefore based on the idea of the discussants and informants it can be deduce that they are becoming victim of development projects and they have developed pessimist idea, lost their confidence. They didn't have any future plan and waiting for nothing. This is the result of development projects that is done in the study area.

Possession of livestock in the household as Physical capital

Table 5. Percent distribution of respondents by possession of livestock $(N=311)$.

\begin{tabular}{lll}
\hline Type of displacement & Yes\% & No\% \\
\hline Displaced households & 91.7 & 8.3 \\
Non displaced household & 96.1 & 3.9 \\
\hline
\end{tabular}

Source; household survey, 2017.

Table 5 shows possession of livestock in the household. $91.7 \%$ of displaced and 96.1 non displaced households have their own livestock whereas $8.3 \%$ displaced and $3.9 \%$ nondisplaced households of the respondents do not have livestock in their household preceding the survey

Respondents who reported possession of livestock were asked their average livestock ownership by using a standard measurement known as tropical livestock unit or TLU. TLU is varied based on the type of the livestock. Accordingly, an $\mathrm{ox}=1.1$ TLU, a bull=1.1TLU, a cow $=0.8$ TLU, a mule $/$ horse $=0.8 \mathrm{TLU}$, a heifer $=0.5 \mathrm{TLU}$, a donkey $=0.36$ $\mathrm{TLU}$, a calf $=0.2 \mathrm{TLU}$, a sheep/goat $=0.09 \mathrm{TLU}$, and a hen $=0.013$ [12],in [1] . For this study, cows and oxen are presented since these two livestock's are the most valuable livestock in the locality and the finding is presented in table 8

Table 6. Average Amount of oxen and cows owned among displaced and non-displaced households ( $N=292$ and 265 respectively).

\begin{tabular}{lllll}
\hline \multirow{2}{*}{ Types of Respondents } & Type of livestock & TLU & Std. Deviation & t-Test \\
\cline { 3 - 5 } & & Mean & .739 & $-7.575^{* * *}$ \\
\hline Displaced & Oxen & 1.804 & .774 & $-9.425^{* * *}$ \\
Non displaced & & 2.574 & .493 & .971 \\
Displaced & Cows & 0.936 & 1.56 & \\
Non displaced & & & \\
\hline
\end{tabular}

Notes $* * *=\mathrm{P}<0.001$.

Source; household survey, 2017.

Table 6 showed about average livestock ownership of oxen and cows by displaced and non-displaced households. The average livestock holding by displaced households is smaller than non-displaced households were (1.804 vs. 2.574 for oxen; 0.936 vs. 1.56 for cows respectively). The independent samples t-test result indicated that livestock possession (oxen and cow) for non-displaced households is significantly higher than the displaced households $(t=1-7.575, \quad d f=263$, $\mathrm{p}<0.05$ andt $=-9.425, \mathrm{df}=267, \mathrm{p}<0.05$ for oxen and cow respectively)

Hence, the finding indicated that there is a significant difference in terms of livestock ownership between displaced and non-displaced households. This means non displaced households have larger number of livestock when it was compared with displaced households. 
Table 7. Average number of oxen and cows owned among displaced households before displacement and current possession ( $N=128$ and 117 respectively.

\begin{tabular}{lllll}
\hline \multirow{2}{*}{ Displacement status } & \multirow{2}{*}{ Type of livestock } & TLU & Std. Deviation & t-Test \\
\cline { 3 - 5 } & & Mean & .979 & $10.519^{* * *}$ \\
\hline Before displacement & \multirow{2}{*}{ Oxen } & 2.706 & .740 & $8.750^{* * *}$ \\
After displacement & & 1.804 & 1.120 & .496 \\
Before displacement & Cows & 1.656 & 0.936 & \\
After displacement & & &
\end{tabular}

Notes $* * *=\mathrm{P}<0.001$

Source; household survey, 2017.

Table 7 elucidated the average livestock holding by displaced households before displacement and their current possession of oxen and cows. It indicates that, their current average livestock holding by displaced households is smaller than before displacement for both oxen and cows were $(2.706$ vs. 1.804 and 1.656 vs. 0.936 respectively). A paired samples t-test result showed that ownership of oxen and cows for the households is significantly lower than before they displaced $(\mathrm{t}=10.519, \mathrm{df}=127, \mathrm{p}<0.001$ and $\mathrm{t}=8.75, \mathrm{df}=116, \mathrm{p}<0.001$ for oxen and cows respectively)displacement. It meant that the current livestock ownership among displaced households is very small when it is compared with before displacement.

Discussants shared similar ideas on their number of livestock and they argued that the number of livestock is decreasing from time to time. For the discussants development projects take the lion share for diminishing their livestock. They have lost their land and they told me that if you don't have land to plough how could you have oxen and others animals? So after they lost their farm land they have tried to sharecropping and renting in land to plough but, the expenses for sharecropping and renting in land was too much expensive and at last they were forced to stop farming and sell their cattle especially oxen.

The other reason of decreasing livestock according to informants and discussants is that the land they plough was the source of forage for their cattle and after they lost the farm they couldn't access forage for their animals and they were obliged to sell their cattle. Thirdly around the factory there was a small reserved place for their animal to stay in but, latter on taken and included with the factory and now there is no any place for their animals to stay on. Households are forced to keep their animals at home including their sheep and goat without any forage for their cattle. Hence, according to discussants it is very painful looking at their animals without any forage and they were forced to sell their cattle.

\subsection{Livelihood Strategies of the Household}

Table 8. Percentage distribution of respondents by their livelihood strategies.

\begin{tabular}{lll}
\hline & Types of respondent & Non displaced (n=155) \\
\cline { 2 - 3 } & Displaced (n=156) & $\%$ \\
\hline Livelihood strategies & $\%$ & 92.3 \\
Crop production for consumption and sale & 81.3 & 74.8 \\
Livestock rearing / breeding & 49.7 & 3.2 \\
Livestock fattening & 11.6 & 0.6 \\
Grain Trading & 5.8 & - \\
Trading in livestock & 3.9 & 52.9 \\
Sharecropping and renting in land & 58.7 & 11.6 \\
Renting out land & 1.9 & 8.4 \\
Local agricultural labour (daily labourer) & 14.2 & 11.0 \\
Local non-agricultural labour (daily labourer & 28.4 & \\
\hline
\end{tabular}

Source; household survey 2017.

Table 8 disclosed livelihood strategies of the households that they pursue to achieve their livelihood outcomes and large number of non-displaced $(92.3 \%)$ than displaced $(81.3 \%)$ households' livelihood strategy is crop production. Large number of controls (74.8\%) than the cases $(49.7 \%)$ livelihood strategy is on livestock rearing. Greater proportion of cases (11.6\%) also peruses fattening of animal but smaller number of controls involve on animal fattening which accounts only $3.9 \%$.Compared to the non-displaced, large proportion of displaced households livelihood strategy is depend on agricultural and non-agricultural daily laborer(42.6 vs. 19.4). Larger number of non-displaced than displaced households livelihood strategy is renting outland to the other farmers $(11.6 \%$ vs. $1.9 \%)$

Data from discussants affirms that, in the locality there are no that much plenty of livelihood strategies. The most and predominant livelihood strategy in the locality is solely agriculture. As to the discussants their prime livelihood strategy is plough land; additionally they also breed of animals for different purpose and it is their supplementary livelihood strategy of the residences but it is not as important as land plough. After they lost their farm land, they were forced to change from plough their own land to renting others land though it was not that much effective. 


\subsection{Livelihood Outcomes of the Household}

Table 9. Average household income of respondents with in the year preceding the survey (311).

\begin{tabular}{llll}
\hline \multirow{2}{*}{$\begin{array}{l}\text { Type of } \\
\text { respondent }\end{array}$} & \multicolumn{2}{l}{ Average annual income in ETB } & t-test \\
\cline { 2 - 3 } & Mean & Std. Deviation & \\
\hline Displaced & 23621.79 & 11509.996 & \\
Non displaced & 31005.15 & 10972.780 & $-5.789 * * *$ \\
\hline
\end{tabular}

Notes $* * *=\mathrm{P}<0.001$.

Source; household survey 2017.

Table 9 elucidates the average annual of income of the households. Displaced households had smaller amount of average annual income when it is compared with nondisplaced households were (23621.79, and 31005 respectively). Independent samples t-test result elucidates that average annual income of the displaced households is significantly higher than displaced households $(t=-5.789$, $\mathrm{df}=309, \mathrm{p}<.001)$.

Table 10. Average household income of displaced respondents before and after displacement $(N=156)$.

\begin{tabular}{llll}
\hline \multirow{2}{*}{ Displacement status } & \multicolumn{2}{l}{$\begin{array}{l}\text { Average annual income in } \\
\text { birr }\end{array}$} & \multirow{2}{*}{ t-Test } \\
\cline { 2 - 3 } & Mean & Std. Deviation & \\
\hline Before displacement & 30051.46 & 14344.247 & \\
After displacement & 23668.79 & 11488.147 & $9.946^{* * *}$ \\
\hline
\end{tabular}

Notes $* * *=\mathrm{P}<0.001$

Source; household survey 2017.

Displaced households were also asked about their average annual income before displacement and their current average annual income and it is summarized on table 10. The average annual income of displaced households before displacement and their current annual income is 30051.46 and 23668.79 respectively. The paired sample t-test result indicates that the current average annual income of displaced households is significantly declining than before they lost their land $(\mathrm{t}=$ 9.946, $\mathrm{df}=156, \mathrm{p}<.001)$. Therefore the finding unveil that there is a significance difference in average annual income means that the average annual income of displaced households decreases when it is compared with after they lost their farm land.

Table 11. Percent distribution of respondents by their experience of food shortage during the last 12 months $(N=311)$.

\begin{tabular}{lll}
\hline \multirow{2}{*}{ Type of respondent } & \multicolumn{2}{l}{ Households experience of food shortage } \\
\cline { 2 - 3 } & Yes & No \\
\hline Displaced & 34.6 & 65.4 \\
Non displaced & 18.1 & 81.9 \\
\hline
\end{tabular}

Source; household survey, 2017.

Table 11 shows us food security issues of the household and to do this an assessment was done whether there was shortage of food or not in the last 12 months preceding the survey. The data revealed that greater number of displaced households (34.6\%) than the non-displaced (18.1\%) experienced food shortage in the last twelve months preceding the survey.

Respondents who experienced food shortage during the last twelve months were asked for how money months did they experience food shortage and it is summarized in table 33

Table 12. Percent distribution of households experience of food shortage by number of months $(N=82)$.

\begin{tabular}{lll}
\hline \multirow{2}{*}{ Type of respondent } & Number of months \\
\cline { 2 - 3 } & $\mathbf{1 - 2}$ & $\mathbf{3 - 4}$ \\
\hline Displaced & 83.3 & 16.4 \\
Non displaced & 96.4 & 3.6 \\
\hline
\end{tabular}

Source; household survey, 2017.

Table 12 shows the number of months for shortage of food and $83.3 \%$ of displaced and $96.4 \%$ of non-displaced households faced shortage of food for one up to two months in a year. Compared to non-displaced (3.6\%), greater proportion of displaced households $(16.4 \%)$ experienced food insecurity for longer months i.e. 3-4 months in a year.

Respondents were also asked about their perceived change in their household food security in the last five years preceding the survey and it is summarized under the following table.

Table 13. Percent distribution of respondents based on the current living condition of the households $(N=311)$.

\begin{tabular}{|c|c|c|c|}
\hline & Displaced household & Non displaced & $\chi^{2}$ \\
\hline & $\mathrm{n}=156$ & $\mathrm{n}=155$ & \multirow{5}{*}{$55.421 * * *$} \\
\hline Doing well (meets household needs with extra stores or savings) & 0 & 19.8 & \\
\hline Doing just okay (meets household needs without & 39.7 & 54.8 & \\
\hline Struggling (managing to meet household needs with supports) & 55.1 & 23.2 & \\
\hline Unable to meet household needs (depends on support) & 5.1 & 2.6 & \\
\hline
\end{tabular}

Notes $* * *=\mathrm{P}<0.001$

Source; household survey 2017.

Table 13 reveals the percentage distribution of sample households living condition and large proportion of displaced households (55.1\%) than non-displaced households (23.2) are struggling. Greater numbers of non-displaced households are doing well than displaced households (19.8\% and $0 \%$ respectively). In addition to this large proportion of nondisplaced households meet their household needs than displaced household's $(54.8 \%$ and 39.7 respectively. current living. $5.1 \%$ of displaced and $2.6 \%$ non-displaced households couldn't meet even household basic needs. Therefore the result shows that there is a significance association between land lose and current living condition households since $\mathrm{x}^{2}=55.421, \mathrm{df}=3, \mathrm{p}<0.001$ meaning large number of displaced households is struggling when it is compare with non 
displaced households.

\section{Discussion}

The major finding of this study got via survey and qualitative data collection instruments; is discussed as follows by relating the findings and results with previous researchers.

Livelihood resources (capital) of the households

In terms of the livelihood assets/resources of displaced households, the finding of this study revealed that their natural capital (land) of the households is smaller when it is compared with those non displaced households (1.45 ha vs. $1.1 \mathrm{ha})$. The finding also reveals that the land holding size of displaced households is diminishing when it is compared with before they lost their farm land because of deemed development projects.

According to [23] revealed that household heads have lost an average of 2.55 hectares of agricultural farmland due to urban expansion. Another study done by [5] discloses that $92 \%$.householdsaverage land size of the peri-urban community had been minimized by 1.58 ha. For this study household heads lost an average of 0.57 ha of land. Though the amount land lost is different in size, this research is similar findings with previous researchers. Therefore the finding of this research goes along with earlier researchers though there is a difference in the size farm land they lose.

The social capital (social interaction in the existing sociocultural institutions), this study come up with that households minimizes their participation after they lost their farm land; Previous findings on social capital such as [6] revealed that social assets of the dislocated farming community have changed due to urban expansion [2] also disclosed that there was a declination of social capital of the community after urban expansion. [2] aslo reported that that there was weakening of social capitals of the community due to disperse offamilies, relatives, neighbors and members of the social networks to different location to search for residential house during relocation. Similar study by [11] reveals that the social ties of the peri urban farming communities declined because of urban expansion.

The other imprtant thing which is included under this paper is ownership of livestock in the households and this study reveals that the number of livestock owned by the household minimizes too much after they lost their farm land. Earleir researchers such as [7]; reveals that expropriation of farm landresulted in loss of land related capitals such as, livestock rearing; the livestock of dispossessed households has declined. According to these researchers, the main reason for declination was lack of access of staying especially for their milk cows and sheeps. The same is true for this reseach.

\subsection{Livelihood Strategies}

The finding of this study reveals that displaced households didn't change that much their livelihood strategy. Despite they lost their farm land, most small holder farmers in the study area still they highly depend on agriculture. They were agrarian societies and still they are dependent on agriculture in one way or another way.

Most studies that have been done in Ethiopia revealed that those households who lost their residence and farm land were forced to change their livelihood strategies.[6]reported that dislocated households pursued different livelihood strategies among others daily labor including guarding, Gombiso making, local alcohol making, water vending and urban and peri- urban agriculture were the main livelihood strategies that were pursued by the dislocated farming communities [7] also revealed that households engaged in to different livelihood strategies such as migration to rural areas and pursued small farming while some others who were wealthy and powerful even before moved in to urban centers and set up their own urban business. A study done by [8] reported that households were involved in off farm activities like daily laborer, guard, water vending and the like. From this it can be deduced that in households who were displaced and dispossessed their farm land in the urban areas and big cities have changed their livelihood strategy. But this study is quite different from previous researchers because in the study area, displaced households didn't change that much their livelihood strategies. To that end the lesser availability of different livelihood strategies is the main reason for those households hinder them involve in different livelihood strategies.

\subsection{Livelihood Outcomes}

Under this study, livelihood outcome of the households was measured by annual income of the households and food security. This study revealed that annual income of the displaced households decreases when it is compared with their counter parts and also before they lost their farm land. The same report has been reported by [6] that $(57 \%)$ of the household heads annual income is decrease when it is compared with before displacement. [7] Also reported that the annual income of displaced households declined too much as compared with before displacement. In terms of food security in the study area, $34.6 \%$ of displaced households faced food insecurity in the last twelve months. [10] A study on Uganda indicates that most of the households $(90 \%)$ faced food insecurity and the reasons ranged from having small pieces of land, poor yields, poor soils and large families. According to [2] development projects creates landlessness by which displaced households lead to joblessness and loss of source of income which eventually resulted in failure of food security and livelihood disorder among many displaced households. [11] also reported that urban expansion is one of the basic problems that affect the living standard and food security of many displaced households.

\section{Conclusion and Implications}

\subsection{Conclusion}

This study examined the impact of development induced 
displacement on the livelihood of small holder farmers among Dejenworeda three rural kebele's and under this section it is tried to summarize the main findings of the study and it is also forwarded some implication for different stakeholders.

In terms of natural capital, displaced households have lower amount of farm land than those of non displaced households the current average amount of land owned by displaced households is about 1.1 ha whereas non displaced households have an average of 1.5 ha of farm land. With respect to social capital there is difference in the level of participation between displaced and none displaced households. In the case of physical capital especially ownership of livestock, the finding shows there is a greater difference between displaced and non displaced households. Non displaced households have greater number of livestock than non displaced households

Majority of the households involve in agriculture and a very few household members involved in nonfarm activities. The finding also revealed that there is some difference in livelihood strategy between displaced and non displaced households. Large numbers of non displaced households involve in production of crop by using their own land whereas displaced households involved in agriculture but on renting in and sharecropping land from other households and some of them involve in nonfarm activities such as daily laborer.

There is a greater variation in terms of annual income between displaced and non displaced households (23,000 vs. 31000 respectively).In terms of food security and larger proportion of displaced households faced food insecurity as compared to non displaced households (34.6 vs. 18.1). The finding also revealed that the current perceived wellbeing of the household who lost the farm land is becoming life threatening. Therefore it becomes a very serious issue for these householders and they are becoming vulnerable of losing everything.

In relation to the expropriation process the finding reveals that households were not invited in any kind of discussion and meeting. Majority of displaced households were not participated in the valuation process the land that has been expropriated. The valuation as well as the asset inventory was not totally transparent for the displaced households. Majority of displaced households believe that the amount of money they got as a compensation was not fair and enough when it is compared with what they lose

The finding reveals that there was no any kind of training given for displaced households.

\subsection{Implications of the Study}

\subsubsection{Implication for Social Worker}

As it is indicated on the analysis and presentation part, households in the study area are becoming victim of development projects. They have lost their farm land, livestock; their livelihood strategy and the living condition of displaced households become worse and worse. Therefore based on the finding of the study the following issues are forwarded as Implications for the concerned bodies.

Social work practitioners can work as a planner enabler, catalyst, coordinator, and teacher of problem-solving skills and applied locality development model to bring about a change in collaboration with the local community.

In addition to this, the finding revealed that there was no pre and post expropriation training to the land holders. Therefore, social workers could provide locality oriented trainings (especially livelihood strategies) that can enable displaced households to cope up with the problem they are facing and it will be very helpful to rebuild their livelihoods easily.

\subsubsection{Implication for the Government}

The government should bring a benefit package for the households but there are no any benefit packages for the households except paying compensation and the government should stop top down approach rather it has to listen the voice of the land holders before forcing them to leave their farm land with continuous meetings and discussions with the community before expropriation.

The finding revealed that the amount of money paid as compensation is no fair therefore government should provide appropriate compensation for displaced households in addition to this, though there was some room for compliance, in practical, households who complain on the compensation didn't have proper answer from those officials. Rather they were forced to accept without any complain. Therefore the must be proper answer for compliances

According to discussants the amount of money as compensation is given by calculating for ten consecutive years meaning according to their agreement the land is expropriated for ten years but after ten years there is no contract renewal. Hence the government with the investor should think over it and renew the contract after the contract is expired so as to benefit small holder farmers.

This research is delimited on Dejen woreda rural kebeles and I recommend future researchers to incorporate more than two woreda's and might cover large areas and it will be very helpful to generalization. Future researchers may do a research by selecting either of the three concepts (livelihood resources, strategies or outcome) and might come up with detail analysis since they can be an independent research.

\section{References}

[1] Agerie Nega. (2013). Determinants of Smallholder Rural Farm Households ' Participation in Small Scale Irrigation and Its Effect on Income in North Gondar Zone: A CrossSectional Approach ( Evidence from Dembia Woreda. Mekele University.

[2] Bikila Ayele. (2014). The Impacts of Development-Induced Displacement and Relocation on the Livelihoods of Households in Dukem Area. Addis Ababa, Ethiopia.

[3] Broughton, A. (2013). Land Grabbing: A New Colonialism, (April 2008), 25-29. 
[4] Cernea, M. M. (1997). Development induced and conflictinduced IDPs : bridging the research divide.

[5] FDRE (Federal Democratic Republic of Ethiopia), 1995. The Constitution of the Federal Democratic Republic of Ethiopia.

[6] Feyera Abdissa. (2005). Urban Expansion and the Livelihood of the Peri-Urban Agricultural Community: The Case of Addis Ababa.

[7] Firew Bekele. (2010). The Impact of Horizontal Urban Expansion on Sub- Urban Agricultural Community Livelihood: The Case of Tabor Sub-City, Hawassa city, Addis Ababa University, Addis Ababa.

[8] Irit, E., \& Weyni, T. (2011). Rebuilding livelihoods after daminduced relocation in Koga, Blue Nile basin, Ethiopia. Bonn, Germany.
[9] Leulsegged Kasa, Dawit Alemu, Zeleke Gete, Fisum Hagos, \& Andreas Heinimann. (2015). Impact of Urbanization of Addis Abeba City on Peri-Urban Environment and Livelihoods, (January 2015).

[10] Nampungu, P. (2011). An Assessment of the Impact of a Government Involuntary Relocation and Resettlement Program on the Livelihoods of Development-Induced Displaced Populations. Oxford Brookes University.

[11] Teketel Fikadu. (2015). Urban Expansion and Its Effects on Peripheral Farming Communities: The Case of Hosanna Town, Hadiya Zone, SNNPR, Ethiopia. Haramaya University, Haramay.

[12] Terminski, B. (2012). Development-induced displacement and human security : a very short introduction. 